\title{
Implementation of Leadership Style to Improve The Quality of Education
}

\author{
Irwan Suryadi \\ Universitas Pendidikan Indonesia \\ torangga@gmail.com
}

\begin{abstract}
Improving the quality of education is to improve educational services in the form of teaching and learning in the classroom, and technical service of educational operation that brought the climate change in the community, there are several important indicators in order to achieve the quality of education, which is good for schools or educational institutions that include, (1) Physical or school facilities and infrastructure, (2) The process of delivering, hospitality and excelent service; which is fast, accurate, responsive and rewarding for students. (3) Responsiveness of the management, teachers and employees or staff indicated they were good with a better administrative process, it is easy to find, so as to reflect the needs of learners. (4) The ability and competence of head of school / head (5) in the end a genuine concern as well as the positive role of all elements of education to understand the needs of learners. From these indicators, the role of leader or principal has a great influence for the improvement of the quality of education, as well as an improvement and growth for institutional development. One of the factors that determine the progress of an organization is the leadership style of a the leader, how a leader who has the character which will either be able to lead his subordinates wisely and will bring its institutions that led to the change towards goodness.
\end{abstract}

Keywords-Quality of Education, Educational Services, Leadership Style

\section{INTRODUCTION}

\section{A. Background}

Education has an important role in improving the Human Resources (HR), therefore, the training of human resources will be able to understand and have a wide range of knowledge, skills and attitudes as an educated man.

In fact, graduates of Higher Education do not reflect the achievements that can be seeded, there are several factors causing low student achievement (1) Minimum number of qualified teachers, (2) Infrastructures inadequate, (3) Organizational climate is unfavorable, (4) Poor interpersonal communication, (5) Poor leadership

The quality of education is determined by several factors. One of them is the factor of management education. Of course, in this case the school head as education managers were required to have the ability to organize the change of schools in addressing various issues towards the better. Therefore, the principal decision-making is one of the management functions that cannot be avoided, because without proper decision making school objectives will not be achieved.

One of the problems often encountered in educational institutions in Indonesia is the weak skills of principals in making appropriate decisions in dealing with conflicts. Decision-making which is slow, hesitant and sometimes rigid disruption will affect the stability of the educational unit because there are many problems that hang and need to find way out.

The success of a principal as a leader is depending on how it reflects human relationships and interpersonal communication with teachers and administrative staff as well as other higher education communities. Therefore, the rector must be able to manage a variety of devices and the condition of the school so that the teachers, staff, students, parents, and other relevant parties want to work or participate in order to achieve the goals that has been setted by the school.

In short, how the attitude of principals to "make" someone else work in achieving the needs of schools is certainly not easy because as a top leader in the education unit school principals should be able to solve any kind of problems that arise as issues related to academic issues, financial, staffing, student, personnel, facilities and infrastructure as well as the problems associated with teachers, administrative staff and all stakeholders in the education unit is headed.

Appropriate style of leadership is one way of reducing the problems that arise in the school and should avoid creating a pattern of relationships with teachers who rely on power, and instead need to promote functional cooperation.

B. Research Question

The problems are further elaborated in the form of the following research question:

1. Which model of the leadership styles that can be used in Higher Education to improve the quality of education

\section{DESCRIPTION OF THE THEORY}

A. Quality of Education

Guets and Davis as quoted by Tjiptono and Diana stated: "Quality is a dynamic condition related to products, services, people, processes, and environments that meet or exceed expectations."[1]

Heizer and Render (2001) in wibowo stated that quality as the ability of a product or service to meet of the customers need [2], while Russell and Taylor (2000) states that quality as views of the totality and characteristics of the products or services that strive with all our ability to satisfy specific needs[3]. According to Philip Kotler[4] stated that quality is 
the totality of features and characteristics of the products or services that depend on its ability to satisfy stated or implied needs.

Joseph Juran is an expert in the fields of quality, defines the quality of a product or service must be able to meet the expectations of users [5]. According to Juran, there are three main steps that should be taken by an institution in achieving perfect quality, namely: (1) Achieving a structured improvement on a sustainable basis, combined with the dedication and urgency. (2) Conducting training programs broadly. (3) Establish commitment and leadership at the level of higher management. From the three concepts presented by Juran, it can be concluded that the quality of the product or service would be able to work well when there is support from all elements in the organization of the main problems encountered in relation to the quality, as well as constantly make improvements, increased knowledge as well as the commitment of the leadership to continue to promote the quality of a product or service produced.

In the context of education, the notion of quality refers to the process of education and educational outcomes. From the context of the "process", a quality education involved a variety of inputs (such as teaching materials: cognitive and affective), methodology (which varies according to the ability of teachers), school facilities, administrative support and infrastructure and other resources as well as the creation of a conducive atmosphere. Quality in the context of "results" refers to the study results or achievements of the school in any given period of time (whether the end of each quarterly contributions, end of the year, 2 years or 5 years, or even 10 years). Achievement or educational outcomes (student achievement) can be the result of test academic skills, such as general tests, and final exam.

From the exposure of some notion of quality can be concluded; Quality education is the ability of an institution and the education system in empowering educational resources to improve the quality, in line with expectations or educational objectives through effective education and Qualified education to the challenge obstacles and problems to overcome present and future

\section{B. Leadership Style}

According Thoha[6], many leadership styles affect the success of a leader in influencing the behavior of their followers. The term style interpreted in a way that used the leader in influencing followers

Leadership style according to Rivai[7], was the overall pattern of actions of a leader, both visible and invisible by his subordinates. Describe leadership styles consistent combination of philosophy, skills, characteristics and attitudes that underlie behavior. Keating [8], stated that the leadership style applied to the leaders is generally divided into two things, the task-oriented leadership (task oriented) and peopleoriented leadership (human relations oriented). As for Blanchard[9], put forward four basic leadership styles are:

1. Directing Style (directing), Here leaders gave more specific instructions and closely monitor the completion of the task. Patterns of leadership is suitable to be applied to the subordinate whose performance is low but has a good enough commitment.

2. Coaching style (training) Here the leader is using directive and supportive enough. That is, the direction and supervision remain to be done strictly by the leader, but the decision is accompanied by an explanation, request advice from subordinates, and will support progress. Patterns of leadership is suitable to be applied to the subordinate has sufficient performance and have a high commitment.

3. Supporting force (support) here given more supportive than directive, particularly for subordinate commitment unfavorable. Leaders with this style more to provide facilities and support the efforts of subordinates toward resolving their duties.

4. Delegation style (delegating) This style is implemented for subordinates who has become a "person of trust". Directive and not much given supportive. Therefore, leaders more often puts decision-making and responsibilities to subordinates

In essence, the use of force in leading the difference caused by motivation or orientation of the leadership in their duties. Lewin cited Luthan ${ }^{1}$, suggests three styles of leadership in education is often used or encountered, namely:

1. Autocratic leadership style (authoritarian).

Autocratic leadership style is the style of a leader who is more focused on the authority, to be dictating, taking a decision unilaterally and provides certain restrictions on the participation of subordinates. Autocratic leadership style can be interpreted as an act according to the will of its own, all considered to be true and subordinates should not be doing activities outside led instruction.

2. The democratic leadership style.

Democratic leadership style is a style in the lead that involve subordinates in decision making, provide employment and opportunities authority as well as the participation of subordinates in various ways. Style of leadership is based on the assumption that just because of the integration dynamic group, organizational goals will be achieved.

3. Laissez faire leadership style.

Laissez faire leadership style is also known to freely control style is a style that is more likely to give full freedom to subordinates in decision making and implementation process of work. In this leadership style, the leader handed over all the responsibilities and work to subordinates or to all members. Leaders here only act as a symbol, with all sorts of flashy decorations or ornaments.

From the study of the theory of the above, it can be concluded that the principal's leadership style is the

1 Fred Luthan. 2006. Perilaku Organisasi. (Alih Bahasa: Muharjanto). Yogyakarta. ANDI, hal. 685.. 
behavior of educational leaders who have the ability and skills in influence, mobilize and empower all the resources available to a school in affecting residents educators to optimize the entire ability to achieve educational goals

\section{DISCUSSION}

Qualified education is the desire of human education throughout the world, including Indonesia. An indicator that show education services are of good quality as follows:

1. Many of the absorption by the market or consumers, in the sense that the resulting product widely used by consumers, for example, The lights (Philip Branded)., his general consumers will choose this product because of the power and last longer than similar products. Similarly, the world of education, the quality of graduates of an educational institution graduates will look when it is able to be absorbed by the world of work.

2. Expensive, generally high-quality products that do not come with a low price but require more funds to get her.

3. Branded Product, at this level generally any branded product has a good quality, as well as educational institutions when an institution has a strong legitimacy then a quality at stake.

Judging from the exposure, a quality of education must be running when the wheels of an organization go hand in hand and in rhythm, conflicts and problems that arise also encourage activity or movement organization works in accordance with the vision, mission and goals of the organization.

As the problem set early part of this article, that there are some important indicators that can foster a quality of education including the factor leader. Leaders in this case plays a very crucial for the sake of reciprocation of an organization,

Addiction figure of a leader is a role that may not be met in order to progress the organization or institution, moreover, a leader who has the right leadership style will create a positive effect to subordinates in order to implement the vision and mission organizations.

The implementation of a leadership style that is applied in an educational institution can not be implemented if only using one type of leadership style, for example Autocratic, Democratic or Laissez Faire. This is because the circumstances are often not supported to implement one of the three styles of leadership. But from the standpoint of the convenience and versatility of the change in an organization, then the style of democratic leadership is a leadership style that is most frequent and feasible to implement school environment or education, this refers to the implementation of the educational process at one college where the authors carry out the research.

Observations by the author over a period sufficient at the university showed that the leadership will be undertaken by the head or the head of the college was able to bring changes in the organization was phenomenal, it can be seen from its development into one of the colleges are quite diperhitungakan in the region.
Reflecting on the democratic leadership style, there are several important factors that needed a leader to develop educational institutions, among them are:

1. As a leader you should always act like a torch or a candle. In this level deifying a leader as a torch or a candle that is capable of illuminating direction or path when subordinates need instructions or guidance on how and what to do in carrying out any activity.

2. As a leader should act as a fountain. In this level a leader able to translate and delegate brilliant ideas to be are conducted by subordinates and also captures and summarizes the resources to subordinates carried out in a process of development and organizational objectives.

3. As a leader should act as umbrellas, the role of a leader become a haven for subordinates of any problems, like an umbrella that can protect a person from the sun and rain.

4. As a leader should behave as a shepherd. In this level is capable of being a leader worth his herdsman which has a great responsibility on the shepherd, giving the same love in every shepherd and give firmness and wisdom are the same on each shepherd.

5. As a leader let to act like a telescope, in which a leader should have the ability, foresight and knowledge at the level of knowledge, organization and conditions of the member or his subordinates.

6. As a As leader let behave like Prophet Muhammad, because by his example was able to bring Muslims into a better life. Thereby, every policy will be implemented with the joy by subordinates.

Of the several factors mentioned above, there are several important characters in order to support a person in the discharge of his leadership as follows:

1. Honestly, an attitude of honesty from a leader is needed, when the information that would be submitted to the subordinate nothing is reduced or added.

2. Ttrustful and trustworthy, a form of great responsibility for how a leader capable of holding the trust of the people who led her and delegating the leadership to him to run the organization toward a goal that at launch palm.

3. Clever, certainly requirement that a leader must be good at science that has flexibility over his subordinates, able to organize subordinates and able to call his subordinates carry out the work programs which have been agreed.

\section{CONCLUSION}

Quality in the field of products and services even more of an educational institution of a fixed price and the non-negotiable - bargaining, because it's an educational institution must have a vision that is far ahead in order to constantly improve the service for learners, both in terms of the quality of school facilities and infrastructure that 
adequate, increasing educators who are able and qualified to the teaching curriculum that is appropriate in order to produce the quality of an educational institution is able to speak a lot to the development of learners at the next level is to produce quality graduates.

From the point of policy, the quality of an educational institution is inseparable from the role that the leadership of policy makers, the implementation and development of an organization or educational institution relies heavily on its strong and weak force a leader in running the organization. Authoritarian leader or leader Laissez faire tend to be difficult to use and will produce many disappointments arising from subordinates. Meanwhile the democratic style is more likely to be adopted in the system or style of a leader in leading organizations of or institution.

\section{REFERENCES}

[1] Fandy Tjiptono \& Anastasia Diana, "Total Quality Management" Yokyakarta, pp 4.2001

[2] Wibowo, “Manajemen Kinerja”, Edisi ketiga, Erlangga, Jakarta, pp 137-138, 2012

[3] Wibowo, “ Manajemen Kinerja”, Edisi ketiga, Erlangga, Jakarta, pp 137-138, 2012.

[4] Philip Koetler, Kevin Lane Keller, “ Manajemen Pemasaran”, Erlangga, Jakarta, pp 143, 2009

[5] Fandy Tjiptono \& Anastasia Diana, "Total Quality Management" Yokyakarta, pp53, 2001.

[6] Miftah Thoha, "Perilaku Organisasi, konsep dan aplikasinya", Rajawali, Jakarta, pp 265, 1996.

[7] Veithzal Rivai, "Kepemimpinan dan Perilaku Organisasi", Raja Grafindo Persada, Jakarta, pp 64, 2008

[8] Keating Charles, J, "The LeadershipBook" Translation by AM. Mangunhardjana,'Kepemimpinan;Teori

Pengembangannya”,Kanisius, Yogyakarta, pp 11, 1986.

[9] Kenneth Blanchard,et.al, "Leadership and the one minute manager", Translation by, Agus Maulana," Kepemimpinan dan Manajer Satu Menit; Meningkatkan Efektifitas Melalui Kepemimpinan Situasional", Erlangga, Jakarta, pp 129, 1992.

[10] Fred Luthan, "Perilaku Organisasi", Translation by ; Muharjanto, ANDI, Yogyakarta, pp 685, 2006.

[11] Courland L. Bovee, Merian Burk Wood, John V. Thill \& George P. Dowel, “ Management”, McGraw-hill inc, New York, 1993

[12] Don B. Tropman \& George P. Donald, "Managerial Planning", Jossey Bass Publ, San Fransisco, 1991.

[13] John W. Newstrom and Keith Davis, " Organizational Behaviour : Human Behaviour at Work", Translation : Agus Dharma, 10th Edition, Tata Mc Graw-hill, New Delhi, 2001

[14] Salis, Edward, “ Total Quality Management in Education “, Taylor and Francis e-Library, London, 2005

[15] Shelton, “ Paradigma Baru Kepemimpinan “, Translation by : Oka, Alex Media Komputino, Jakarta, 2002.

[16] Garry Yuk1, “ Leadership in Organiztion “, Translation by : Busi Suprianto, “ Kepemimpinan dalam Organisasi “, PT. Indeks, Jakarta, 2009

Jurnal:

Analisis Pengaruh Gaya Kepemimpinan dan Motivasi Kerja terhadap kinerja pegawai pada Dinas Tenaga Kerja Propinsi Lampung, Agustuti HAndayani, Jurnal Ilmiah Administrasi Publik dan Pembangunan, Vol.1, No.1, Januari - Juni 2010

Author Archives. 2009. Macam-macam Gaya kepemimpinan. http://jurnalsdm.blogspot.com

Does School Quality Matter? Returns to Education and the Characteristics of Public Schools in the United States David Card; Alan B. Krueger
The Journal of Political Economy, Vol. 100, No. 1. (Feb., 1992), pp. $1-40$.

Journal of Leadership Education Volume 11, Issue 1 - Winter 2012 Copyright 2012 by the Association of Leadership Educators. All rights reserved. ISSN 1552-9045

Leadership \& Organization Development Journal, Emerald Article: Transformational leadership and personal outcomes: empowerment as mediator Venkat R. Krishnan, Leadership \& Organization Development Journal, Vol. 33 Iss: 6 pp. 550 - 563, http://dx.doi.org/10.1108/01437731211253019

The Behavioral Consequences of Service Quality ValarieA. ZeithamI, Leonard L Berry, \& A. Parasuraman 